\title{
Indigenous Claim Supports in vitro Antioxidant and Cytotoxic Screening of certain South Indian Medicinal Plants
}

\author{
ShakkeelaYusuf $^{\mathrm{a}}$, K.K.Srinivasan ${ }^{\mathrm{b}}$, Jyoti Harindran ${ }^{\mathrm{c}}$ \\ ${ }^{a}$ Department of Pharmaceutical Sciences, Cheruvandoor Campus, Ettumanoor, Kottayam, Kerala, India- \\ 686631. \\ ${ }^{b}$ Department of Chemistry, Shri Madhwa Vadiraja Institute of Technology and Management, (Affiliated to \\ VITU, Belgavi), Bantakal, Udupi, Karnataka -574115. \\ ${ }^{c}$ Principal and Research Director, Department of Pharmaceutical Sciences, Mahatma Gandhi University, \\ Cheruvandoor Campus, Ettumanoor, Kottayam, Kerala, India-686631.
}

\begin{abstract}
Plant drugs enjoy much acclaim and wide acceptability even in the midst of amazing advancements in modern medicine. Current research in drug discovery from medicinal plants involves a multifaceted approach combining botanical, phytochemical, biological and molecular techniques. Evaluation of certain selected south Indian medicinal plants popularly used in Indian system of medicine has been taken up for their antioxidant and cytotoxic activities. The plants selected were Heliotropium indicum, Schleichera oleosa, Shorea robusta, Symplocos cochinchinensis and Wrightia tinctoria. Antioxidant activities involved DPPH, total antioxidant, iron chelating and nitric oxide assays. Cytotoxicity assay was carried out by MTT using SKMEL-28 and HCT-15 cell lines. Results obtained could very well support the therapeutic claims made for the investigated plants.
\end{abstract}

Keywords: antioxidant, cytotoxic, DPPH, iron chelating, MTT

\section{Introduction}

Heliotropium indicum is used in the local application for ulcers, wounds, sores, gum boils and skin infection (1). Schleichera oleosa bark aqueous extract is astringent in nature. It is mixed with oil and applied externally in skin eruptions. Seed oil is used for massage in rheumatism and applied in alopecia, itch and acne. It is claimed to stimulates hair growth (2). Shorea robusta resin is popularly known as 'sal resin' is an antioxidant, astringent, detergent, antidiarrhoeal, antidysenteric and has antiseptic action, hence used in skin diseases (3). Wrightia tinctoria bark preparation finds use in the control of dysentery, piles and skin diseases (4). Bark and seeds are prescribed in flatulence and bilious affections (5). Symplocos cochinchinensis is traditionally used for the treatment of diarrhoea, dysentery, eye diseases, hemorrhagic gingivitis, uterine disorders, menorrhagia, bowel complaints, ulcers, snake bites, malaria and enteritis (6). Uncontrolled production of reactive oxygen species cause damage to living organisms which can be prevented by the use of free radical scavengers or antioxidants (7). Also, assessing the potential to inhibit the viability of cells in two human cancer cell lines namely skin and colon carcinomas by MTT assay would be worthwhile to explore the scope of these much used medicinal plants.

\section{Materials and methods}

S. robusta and W. tinctoria barks were collected from Idukki District, Kerala and Heliotropium indicum, Schleichera oleosa and Symplocos cochinchinensis were collected from Thengamom, Pathanamthitta District, Kerala during September 2010. These were authenticated by Mr. Rogimon. P. Thomas, Assistant Professor Department of Botany, C.M.S College, Kottayam, Kerala.

\subsection{Preparation of the extract}

Shade dried plant material was soaked in ethanol (95\%) overnight and then refluxed for three hour; the clear extract was decanted off; it was repeated thrice. The extracts were pooled and concentrated by distillation under reduced pressure till a syrupy consistency was achieved. Solvent was evaporated to dryness on a water bath. The dry extract was used for the antioxidant assays and MTT assay (8).

Table: 1 Plants and plant parts used

\begin{tabular}{|c|c|c|c|c|c|}
\hline Plant & H.indicum $(\mathrm{HI})$ & $\begin{array}{l}\text { S. oleosa } \\
\text { (SO) }\end{array}$ & $\begin{array}{l}\text { S. Robusta } \\
\text { (SR) }\end{array}$ & S.cochinchinensis (SC) & $\begin{array}{l}\text { W. tinctoria } \\
\text { (WT) }\end{array}$ \\
\hline Parts used & Whole part & bark & Oleoresin & Bark & Bark \\
\hline
\end{tabular}




\subsection{Antioxidant activity}

Antioxidant activity studies of the TEE of five plants were carried out using different models namely total antioxidant activity by phosphomolybdenum method, DPPH, iron chelating assay by orthophenanthroline and nitric oxide scavenging assay. Active oxygen species and free radicals are involved in a variety of pathological events. Total antioxidant activity was estimated by phosphomolybdenum assay and were expressed as the number of equivalents of ascorbic acid (9). The assay is based on the reduction of Mo (VI) to Mo (V) by the sample analyte and the subsequent formation of green phosphate/Mo (V) complex at acidic $\mathrm{pH}$. The phosphomolybdenum method is quantitative since the total antioxidant activity is expressed as the number of equivalents of ascorbic acid(10). The DPPH is a stable free radical and is widely used to assess the radical scavenging activity of antioxidant compounds. This method is based on the reduction of DPPH in methanol solution in the presence of a hydrogen-donating antioxidant due to the formation of the nonradical form DPPH$\mathrm{H}(11)$. In addition to ROS, nitric oxide is also implicated in inflammation, cancer and other pathological conditions(12).The ferric reduction capacity of the extract was measured as a mark of antioxidant capacity. The reducing powers of all the plant extracts were increasing with concentration dependent manner.

\subsection{In vitro anticancer activity \\ 2.3.1 MTT Assay}

This Colorimetric assay is based on the capacity of Mitochondria succinate dehydrogenase enzymes in living cells to reduce the yellow water soluble substrate 3- (4, 5-dimethyl thiazol-2-yl)-2, 5-diphenyl tetrazolium bromide (MTT) into an insoluble, colored formazan product which is measured spectrophotometrically. Since reduction of MTT can only occur in metabolically active cells, the level of activity is a measure of the viability of the cells(13).

\section{Results And Discussion}

Phytochemical analysis indicated the presence of secondary metabolites like polyphenols, tannins, flavonoids and alkaloids(14). From the Symplocos species betulinic, oleanolic, acetyl oleanolic and ellagic acids reported having cytotoxic and antioxidant presence are reported from the plant. Glycosides, isolated from the ethanolic extract of the stem bark are highly astringent, and are reported to be responsible for the medicinal properties of the bark (15). Sterols schleicherastins (1-7) and two related sterols such as $8 \& 9$ designated as schleicheolos $1 \& 2$ are isolated from the Schleichera oleosa(16). Aerial parts of H.indicum contain pyrrolizidine alkaloids, indicine (principal), echinitine, supinine, heleurine, heliotrine, lasiocarpine, its N-oxide, acetyl indicine, indicinine and antitumor alkaloid, indicine-N-oxide. The plant also contains rapanone, lupeol and an ester of retronecine. Roots contain high amount of estradiol (17).

\subsection{Antioxidant activity}

TEE of all the five plant extracts showed very potent total antioxidant capacity. On the basis of results of the four assays each plant extract contributes in one way or other towards the antioxidant activity, with a clear gradation becoming difficult(18)(17). Nitric oxide scavenging assay of all the five TEE of the plants were evaluated at a concentration of 125 to $2000 \mu \mathrm{g} / \mathrm{mL}$ and the results were compared with the standard ascorbic acid. (19). The scavengers of nitric oxide compete with oxygen, leading to reduced production of nitrite ions. Large amounts of NO may lead to tissue damage (20).

Table: $2 \mathrm{IC}_{50}$ values of antioxidant screening of the plants by iron chelating, DPPH, nitric oxide and total

\begin{tabular}{|c|c|c|c|c|c|}
\hline \multirow[t]{2}{*}{ Sl.no: } & \multirow[t]{2}{*}{ Plant extracts } & Iron chelating & DPPH & Nitric Oxide & \multirow{2}{*}{$\begin{array}{l}\text { Total antioxidant activity (Ascorbic } \\
\text { acid Equivalents /100gextract) }\end{array}$} \\
\hline & & \multicolumn{3}{|c|}{$I C_{50}(\mu \mathrm{g} / \mathrm{mL})$} & \\
\hline 1 & WT & 86.64 & 166.77 & 864.20 & 55.8 \\
\hline 2 & SR & * & * & 522.74 & * \\
\hline 3 & HI & 71.05 & 259.45 & 1295.37 & 74.8 \\
\hline 4 & SO & 147.517 & 62.29 & 1224.24 & 131.4 \\
\hline 5 & SC & 362.406 & 174.55 & 1313.47 & 119 \\
\hline 6 & STD & 37.59 & 17.25 & 157.10 & - \\
\hline
\end{tabular}

*reference(3)

In each case for iron chelating assay, H.indicum showed 71.05, DPPH assay, Schleichera oleosa given 62.29 and for nitric acid assay, Shorea robusta showed 522.74 lower $\mathrm{IC}_{50}$ values and higher activity when compared with that of the standard ascorbic acid 37.59, 1725 and $157.10 \mathrm{IC}_{50}$ values respectively. Total antioxidant assay Schleichera oleosa given good quantity (131.4) of ascorbic equivalents when compared with other extracts. The observed results demonstrate a marked capacity of the extract for iron binding, suggesting that their action as a peroxidation protector may be related to its iron binding capacity (21).The results revealed S.robusta and W.tinctoria showed good scavenging property. The $\mathrm{IC}_{50}$ values are tabulated in the table:2 


\subsection{In vitro anticancer activity}

\subsubsection{MTT ASSAY}

An in vitro cytotoxicity study had been carried out by MTT assay for the TEE of all the plants using SKMEL-28 and HCT-15 cell lines. $\mathrm{IC}_{50}$ values of H.indicum, S.cochinchinensis, S. oleosa, S.robusta and W. tinctoria in SKMEL-28 cells were found to be 276.90, 278.71, 81.57, 22.17 and $62.22 \mu \mathrm{g} / \mathrm{mL}$ respectively (22)

Table: 3. $\mathrm{IC}_{50}$ values of plant extracts by MTT assay

\begin{tabular}{|c|l|c|c|}
\hline Sl.no: & \multirow{2}{*}{ Plant extract } & SKMEL-28 & HCT-15 \\
\cline { 3 - 4 } & & \multicolumn{2}{|c|}{$\mathbf{I C}_{\mathbf{5 0}}(\boldsymbol{\mu g} / \mathbf{m L})$} \\
\hline $\mathbf{1}$ & WT & 62.22 & 91.97 \\
\hline $\mathbf{2}$ & SR & $\mathbf{2 2 . 1 7}$ & $\mathbf{6 9 . 5 7}$ \\
\hline $\mathbf{3}$ & HI & 276.90 & 106.98 \\
\hline $\mathbf{4}$ & SO & 278.71 & 77.55 \\
\hline $\mathbf{5}$ & SC & 81.57 & 81.71 \\
\hline
\end{tabular}

The cytotoxic potential investigated indicate that among the five TEE S.robusta imparted the highest growth inhibitory activity in selected human cancer cell line followed by W. tinctoria, S.cochinchinensis, H.indicum and, S. oleosa ( table:3). The anticancer activities of TEE of all plants were evaluated by MTT assay using HCT-15 cell line (table-3) at a concentration of $10,25,50,75$ and $100 \mu \mathrm{g} / \mathrm{mL}$ for $24 \mathrm{~h}$ and the activity varied in a concentration dependent manner. $\mathrm{IC}_{50}$ values of H.indicum, S.cochinchinensis, S. oleosa, S.robusta and W. tinctoria in HCT-15 cell lines were found to be $106.98,77.55,69.57,81.71$ and $91.97 \mu \mathrm{g} / \mathrm{mL}$ respectively.

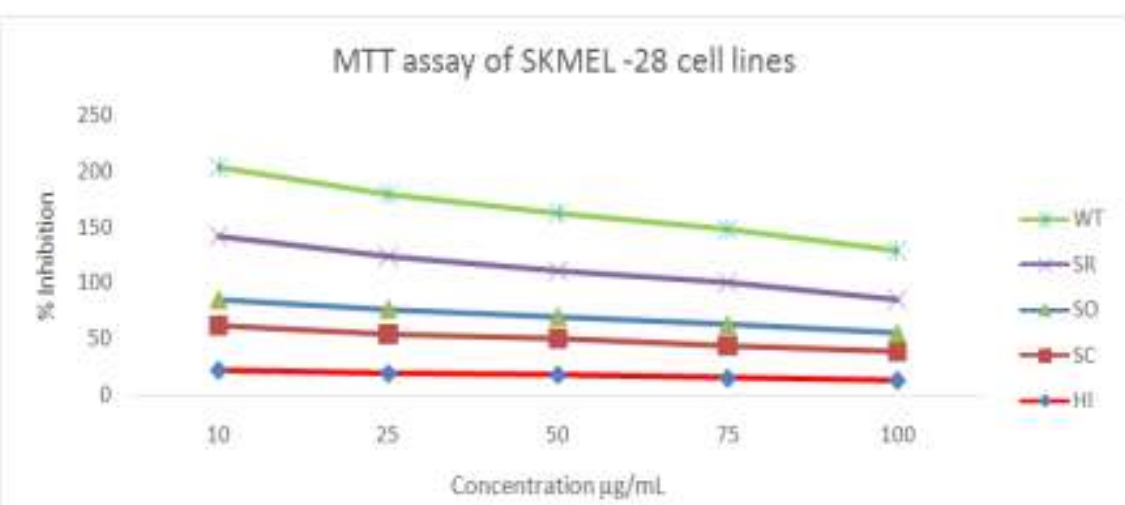

Fig: 1 Comparative evaluation of $\mathrm{IC}_{50}$ values of various extract using SKMEL-28 cell lines by MTT assay.

The cytotoxic potential results indicated that among the five plants TEE of S.robusta imparted the highest growth inhibitory activity in selected human cancer cell line followed by S. oleosa, S. cochinchinensis, W. tinctoria, and H.indicum. In vitro cytotoxicity study of all the five plant parts by MTT assay carried out using SKMEL-28 and HCT-15 cell lines. All the extracts gave good results. Among the plants H.indicum, S.cochinchinensis, S. oleosa, S.robusta and W. tinctoria, S.robusta showed best activity with lowest $\mathrm{IC}_{50}$ values of 22.17 and $69.57 \mu \mathrm{g} / \mathrm{mL}$.

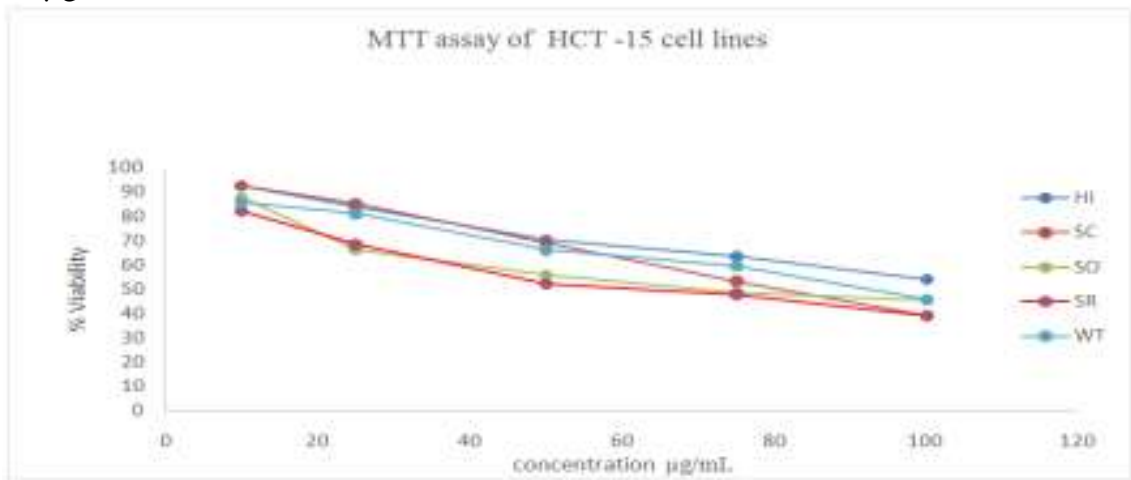

Fig: 2 Comparative evaluation of $\mathrm{IC}_{50}$ values of various extract using HCT-15 cell lines by MTT assay.

The better activity of the plant may be due to the presence secondary metabolites present. All the extracts gave good results, among the plants S.robusta showed best activity with lowest $\mathrm{IC}_{50}$ values of 22.17 and $69.57 \mu \mathrm{g} / \mathrm{mL}$ in SKMEL-28 and HCT-15 cell lines respectively. The cell lines used for the study were colon 
cancer cell lines and skin cancer cell lines. The results revealed the very good activity of the plant $S$. robusta and W. tinctoria as good candidates and confirmed its traditional use.

\section{Conclusion}

The literature review shows the presence of gallic acid, lignan and triterpenoids in the plant (23). Crude extracts of all the five plant parts were prepared and evaluated for in vitro cytotoxic and antioxidant activity. All the extracts did not show hemolytic activity suggesting their biocompatibility. Shorea robusta and Wrightia tinctoria was found to be significantly antioxidant and cytotoxic on the different methods carried out on antioxidant activity and on cancer cell lines in dose dependent manner implying potential antitumor activity of both the plants and scope for further studies. The observed activity of the plant was shown by the whole extract. The activity showed only can be confirmed by the isolation of the particular compound present.

\section{Reference}

1. Srinivas K, Rao MEB, Rao SS. Anti-inflammatory activity of Heliotropium indicum linn.and leucas aspera spreng. in albino rats. Indian J Pharmacol. 2000;32:37-8.

2. Bhatia H, Kaur J, Nandi S, Gurnani V. A review on Schleichera oleosa : Pharmacological and environmental aspects. JOPR J Pharm Res [Internet]. Elsevier Ltd; 2012;6(1):224-9. Available from: http://dx.doi.org/10.1016/j.jopr.2012.11.003

3. Yusuf, Shakkeela KKS. GC-MS Analysis of Oil Isolated and Antioxidant Activity of Shorea Robusta Oleoresin. Am J Pharm Heal Res. 2015;3(11):1-8

4. Devi SL, Divakar MC. Wrightia tinctoria ( Roxb ) R . Br . - An updated Review. Hygeia JD MED. 2014;6(April):95-105. C.P.Khare. Indian Medicinal Plants.

Divakar MC, S LD. Antiulcer activity of Wrightia tinctoria ( Roxb .) R . Br. pelagia Res Libr. 2011;2(2):355-60.

Ck R, Kl R, Ks J, Joyce GS. Comparative evaluation of antioxidant property in methanol extracts of some common vegetables of India. Sch Res Libr. 2011;2(2):86-94.

8. Dinan L. Natural Products Isolation. In: Natural Product Isolation. 1998. p. 279-327.

9. Jagadeesan P, Prasad DA, Pandikumar P, Ignacimuthu S. Antioxidant and free radical scavenging activities of common wild greens from Tiruvallur District of Tamil Nadu , India. 2011;2(June):156-63.

10. Prieto P, Pineda M AM. Spectrophotometric quantitation of antioxidant capacity through the formation of a phosphomolybdenum complex: specific application to the determination of vitamin E. Anal Biochem. 1999;269(2):337-41.

11. Lakshmi K.S and Vadivu R. Preliminary phytochemical and in-vitro cytotoxic activity of the leaves of Symplocos cochinchinensis (Lour.) S.Moore ssp. laurina (Symplocaceae). Sch Res Libr [Internet]. 2010;2(2):208-20. Available from: http://scholarsresearchlibrary.com/ABR-vol1-iss2/ABR-2010-1-2-87-90.pdf

12. S.D. Sanja, Sheth NR, Patel NK, Patel D, Patel B. Characterization and Evaluation of Antioxidant Activity of Portulaca Oleracea. Int J Pharm Pharm Sci. 2009;1(1):74-84.

13. Patel S, Gheewala N, Suthar A, Shah A. In-vitro Cytotoxicity activity of Solanum nigrum extract against HeLa cell line and Vero cell line. Int J Pharm Pharm Sci. 2009;1(1):38-47.

14. C.K. Kokate PSBG. Pharmacognosy. 24th ed. Vallabh Prakashan; 2003. 108-109 p.

15. Varun Kumar Singh RK. Management of Diabetes mellitus and its complications by Lodhra : A review. Int J Ayurvedic Med. 2015;6(4):305-9.

16. Pettit GR, Numata A, Cragg GM, Herald DL, Takada T, Iwamoto C, Riesen R, Schmidt JM, Doubek DL GA. Isolation and structures of schleicherastatins 1-7 and schleicheols 1 and 2 from the teak forest medicinal tree Schleichera oleosa. J Nat Prod 2000;63(1):72-8.

17. Silitonga AS, Masjuki HH, Mahlia TMI, Chyuan H, Kusumo F, Aditiya HB, et al. Schleichera oleosa L oil as feedstock for biodiesel production. FUEL [Internet]. Elsevier Ltd; 2015;156:63-70. Available from: http://dx.doi.org/10.1016/j.fuel.2015.04.046

18. Bhattachajya SK, Satyan KS, Ghosal S. Antioxidant activity of glycowithano lides from Withania somnifera. Indian J Exp Biol. 1997;35(March):236-9.

19. Helen Mary L, Lakshmi, Tilton F, Joseph J, Siddhartha Solosan S, Sudarsanam D. Phytochemical, antioxidant and cytotoxic properties of the fruit extract from cucurbita digitata. Int J Pharm Pharm Sci. 2014;6(4):353-6.

20. Muntané J, Mata M De. Nitric oxide and cancer. world J Hepatol. 2010;2(9):337-44.

21. Shreedhara CS, N ARH, Zanwar SB, Gajera FP. In vitro antioxidant Potential of Ethanolic extract of Momordica dioicaroxb ( cucurbitaceae ). pharmacologyonline. 2011;633:622-33.

22. Arung ET, Wicaksono BD, Handoko YA, Kusuma IW, Yulia D, Sandra F. Anti-cancer properties of diethylether extract of wood from Sukun (Artocarpus altilis) in human breast cancer (T47D) cells. Trop J Pharm Res. 2009;8(4):317-24.

23. Adlakha MK, Kapoor R, Sharma AK, Kotecha M. Phytochemical Study of Shorea robusta ( SHALA ). Int J Pharm Biol Arch. 2013;4(4):663-71. 